\title{
4: 75229451-775226395
}

National Cancer Institute

\section{Source}

National Cancer Institute. 4: 75229451-775226395. NCI Thesaurus. Code C42040.

Physical location of CXCL5_Gene 